\title{
ЗАГАЛЬНА ХАРАКТЕРИСТИКА МОБІЛЬНИХ ТЕХНОЛОГІЙ І ЗАСОБІВ НАВЧАННЯ У ЗАКЛАДАХ ЗАГАЛЬНОЇ СЕРЕДНЬОЇ ТА ВИЩОЇ ПЕДАГОГІЧНОЇ ОСВІТИ
}

\author{
Соя О. М., Тютюн Л. А., Косовець О. П.
}

\section{ВСТУП}

Розвиток цифрових технологій зумовлює удосконалення форм і методів взаємодії учасників освітнього процесу. Особливого значення набувають мобільні технології, у педагогічно-виваженому використанні яких вбачаємо можливості інтеграції мобільних освітніх середовищ у традиційні інформаційно-освітні середовища закладів загальної середньої та вищої педагогічної освіти. Проте мобільність передачі інформації ще не забезпечує передачі знань, культури, мислення, а є лише важливим допоміжним засобом навчання. Гнучкість використання інноваційних методів організації освітнього процесу вимагає правильного відбору змісту навчання відповідно до дидактичних властивостей і можливостей онлайн-середовищ; прогнозу можливого впливу новітніх технологій навчання на характер мислення та поведінки учасників освітнього процесу.

Метою роботи є представлення моделі використання мобільних освітніх середовищ під час навчання студентів педагогічних закладів вищої освіти; дослідження процесу використання мобільних технологій і засобів навчання у закладах освіти, їхніх переваг, недоліків і вимог до застосування; з'ясування ролі цифровізації освіти, що підвищує якість і доступ до освітнього процесу учнів / студентів 3 особливими освітніми потребами через мобільні освітні середовища.

Ринок надання освітніх послуг стрімко реагує на еволюцію новітніх інформаційних технологій у контексті осучаснення змісту навчання, удосконалення форм і методів взаємодії учасників освітнього процесу тощо. Тому симбіоз методологічних підходів до розвитку освіти за умов інформаційного суспільства ${ }^{1}$, віртуальна освіта й функціональні можливості віртуальних навчальних середовищ закладів загальної та вищої освіти ${ }^{2}$ електронне навчання та забезпечення e-learning

1 Лазаренко Н.І., Коломієць А.М., Клименко А.О. Симбіоз методологічних підходів до розвитку освіти в умовах інформаційного суспільства. Наука і освіта. 2017. T. 4. C. 107-112. DOI: 10.24195/2414-4665-2017-4-18.

2 . Semenets D.A., Soia O.M., Tyutyun L.A. Using of electronic educational content in higher education institutions. Фізико-математична освіта. 2020. Вип. 1 (23). Ч. 2. C. 6-11. DOI: 10.31110/2413-1571-2020-023-1-2-001. 
за допомогою персональних сайтів учителів і викладачів ${ }^{3}$, мобільне навчання та розробка мобільних застосунків для портативних девайсів ${ }^{4}$, вільно поширювані або умовно безкоштовні мережеві ресурси й сервіси та використання навчального контенту онлайн-середовищ зацікавленою особою ${ }^{5} \epsilon$ невід'ємними складовими частинами інноваційного середовища навчання математики. Вони впливають як на рівень і зміст, так і на ступінь забезпечення належного доступу до середньої чи вищої освіти за умов, коли традиційні методи, форми й засоби є недоступними або обмеженими.

На шляху реалізації інклюзивної освіти із використанням мобільних освітніх середовищ у закладах загальної середньої та вищої педагогічної освіти виникають певні технічні труднощі через неякісний зв'язок із глобальною мережею й обмеженою кількістю навчальнометодичної літератури, яка здебільшого $є$ психолого-педагогічними рекомендаціями, не містить практичних прикладів адаптації та модифікації навчального матеріалу із предмету чи дисципліни для забезпечення інклюзивного навчання учнів / студентів 3 особливими освітніми потребами. Тому саме мобільні освітні середовища дають змогу їм розвивати здібності й таланти, отримувати доступ до адаптованих навчальних матеріалів, долати соціально-психологічні перешкоди у навчанні та спілкуванні, а також демонструвати свої навчальні досягнення для здобуття професії.

Використання цифрових технологій та інструментів надає значні переваги для адаптації та модифікації змісту дисциплін для студентів із особливими освітніми потребами. Нечуючі студенти за допомогою програм, що відображають субтитри у мультимедійних лекціях, читають i переглядають навчальний матеріал разом 3 іншими студентами групи. Спеціальні налаштування для операційної системи та встановлення екранного диктора $\epsilon$ необхідною умовою для

3 Тютюн Л.А. Соя О.М. Забезпечення E-learning за допомогою персонального сайту викладача. Сучасні інформаційні технологї та інноваційні методики навчання: досвід, тенденції, перспективи : збірник наукових праць II Міжнар. наук.практ. інтернет-конф. 3 нагоди святкування 30-річчя кафедри інформатики та методики іiі навчання (м. Тернопіль, 8-9 листоп. 2018 р.). Тернопіль, 2018. C. 247-249. URL: http://conf.fizmat.tnpu.edu.ua/media/arhive/2018.pdf.

4 Серга О.М., Соя О.М. Використання мобільних технологій навчання математики в закладах загальної середньої освіти. Проблеми вищої математичної освіти: виклики сучасності: матеріали Міжнар. наук.-метод. Інтернет-конф. (м. Вінниця, 01-03 червня 2020 р.). Вінниця, 2020. URL: https://conferences.vntu.edu.ua/index.php/pmovc/pmovc20/paper/view/10493.

${ }^{5}$ Соя О. Використання навчального контенту онлайн-середовищ у професійній підготовці майбутніх учителів інформатики та математики. Наукова діяльність як шлях формування професійних компетентностей майбутнього фахівия : матеріали Міжнар. наук.-практ. конф. (м. Суми, 5-6 грудня 2019 р.). Суми, 2019. Ч. 2. С. 156-158. 
створення мобільного освітнього середовища для слабозорих і незрячих студентів інклюзивної групи.

3 огляду на те, що останнім часом менеджерами в системі освіти й науково-педагогічними та педагогічними працівниками здійснюється клопітка робота щодо предметно-технологічної організації інформаційного освітнього простору, впорядкування процесів накопичення i зберігання різних предметних колекцій електронних освітніх ресурсів і навчально-методичних комплексів дисциплін; забезпечення здобувачам загальної та вищої освіти дистанційного доступу до них; покращення IT-підтримки й оптимізація форм і методів процесів навчання, забезпечення якості й управління освітою; проведення різноманітних науково-методичних i практичних досліджень, масштаби впровадження, використання, технічної та програмної підтримки вказаних вище освітніх новацій збільшуються. Повною мірою вони використовуються під час реалізації засад дистанційного навчання, яке дає змогу без будь-якого фізичного контакту досягнути мети та виконати основні завдання, засвоїти інформаційний обсяг навчальної дисципліни, сформувати у здобувачів освіти відповідні компетентності задля досягнення програмних результатів навчання; передбачає можливість застосування в освітньому процесі сучасних методів i технологій навчання, необхідність оволодіння відповідними знаннями й уміннями роботи із сучасними інформаційними ресурсами, здатність використовувати різні форми та методи онлайн-оцінювання тощо. Нині уже маємо досить значний досвід реалізації дистанційного навчання 3 використанням різноманітних телекомунікаційних систем, зокрема на основі комп'ютерних мереж, безпосередньої телевізійної трансляції, з використанням сучасних цифрових технологій.

Стратегічною метою розвитку дистанційного навчання у світі є ідея надання реальних можливостей здобувачам освіти навчатися за освітніми програмами чи вивчати окремі дисципліни будь-якого коледжу або університету незалежно від фізичного місця розташування навчального закладу. Це передбачає перехід від обмеженої концепції фізичного переміщення суб'єктів освітнього процесу із країни в країну до концепції мобільних ідей, знань і навчання на основі розподілу й надання доступу до них за допомогою обміну освітніми ресурсами з використанням комунікаційних каналів.

\section{1. Модель використання мобільних освітніх середовищ у закладах освіти}

Особливість підготовки майбутнього вчителя математики, інформатики та фізики полягає в тому, що сучасний студент, постійно перебуваючи у швидкозмінному інформаційному суспільстві, здатний самостійно отримувати інформацію 3 електронних ресурсів, проте 
виникає необхідність навчити його не лише оперативно шукати потрібну інформацію, а й опрацьовувати, засвоювати та використовувати іiі для кращого розуміння навчального матеріалу 3 математичних дисциплін 6 .

Модель використання мобільних освітніх середовищ у вивченні дисциплін циклу професійної підготовки здобувачів вищої освіти визначаємо як системне поєднання структурних блоків (цільового, змістового, технологічного, результативного), сутність яких характеризує особливості та специфіку організації освітнього процесу, передбачає зважений підхід до формування стійкої мотивації до навчання та вибору форм контрольних заходів і критеріїв оцінювання навчальних досягнень студентів.

Цільовий блок використання мобільних освітніх середовищ базується на:

- меті й основних завданнях вивчення навчальної дисципліни;

- формуванні загальних і фахових (спеціальних) компетентностей здобувачів вищої освіти для досягнення програмних результатів навчання 3 кожної освітньої компоненти відповідно до освітньопрофесійної програми підготовки фахівців з урахуванням особливих освітніх потреб;

- тріаді цілей навчання (освіти, розвитку, виховання), що випливає із загальної дидактики та конкретизується відповідно до освітніх компонентів.

Сучасна система освітніх послуг базується на принципах недискримінації, врахування багатоманітності учнів / студентів, ефективного залучення та включення до освітнього процесу осіб з особливими освітніми потребами. Забезпечити та реалізувати систему інклюзивного навчання у закладах загальної середньої й вищої педагогічної освіти допоможуть мобільні технології та сучасні засоби навчання.

Асортимент мобільних гаджетів збільшується щодня і включає ігрові приставки, цифрові диктофони, зчитувачі електронних книг, електронні словники та допоміжні технології для учнів / студентів 3 особливими освітніми потребами. Мобільні пристрої стають багатофункціональними, 3 можливістю підтримувати розмову, прослуховування, перегляд, читання, письмо, пошук інформації, виконання обчислень тощо. Вибір пристрою залежить від віку, місцезнаходження, завдання та інших чинників. Підлітки та молодь зазвичай використовують мобільні телефони та персональні медіаплеєри. Учасники освітнього процесу можуть мати персональних

6 Semenets D.A., Soia O.M., Tyutyun L.A. Functioning of virtual educational environments in higher education in context of continuous education. Progressive Science Journal. 2019. № 1. P. 28-32. 
цифрових помічників, смартфони та ноутбуки як частину свого обладнання для навчання і роботи.

Не менш важливими є мережі та інфраструктури, які забезпечують підключення пристроїв між собою та до Інтернету, включаючи безкабельні рішення, що дозволяють учням / студентам пересуватися та залишатися на зв'язку. Навігація за допомогою GPS (глобальної системи позиціонування) дозволяє визначити місцезнаходження учасника освітнього процесу; його використання включає спільний доступ до контекстних ресурсів і надання інформації, що стосується подорожі чи певного місця.

Мобільне навчання робить акцент на інтеграції навчання й особистого життя учня / студента з особливими освітніми потребами, тому освіта більше не розглядається як окрема діяльність, яка має здійснюватися у школі, університеті чи іншому закладі.

Змістовий блок моделі використання мобільних освітніх середовищ містить інформаційний обсяг кожної навчальної дисципліни відповідно до її місця в освітньо-професійній програмі (кількості кредитів ЄКТС, загального обсягу, співвідношення кількості годин аудиторних занять i самостійної роботи до загальної кількості годин, розподілу кредитів ЄКТС на тиждень за курсами та семестрами, форм контрольних заходів і критеріїв оцінювання навчальних досягнень здобувачів вищої освіти).

Мобільні технології освітнього середовища дають можливість учасникам освітнього процесу, в т. ч. 3 особливими освітніми потребами, використовувати різноманітні індивідуальні налаштування для зміни способів відображення і сприйняття навчального матеріалу:

1. Змінити способи відображення навчального матеріалу. У друкованих матеріалах відображення даних $\epsilon$ фіксованим і постійним. У правильно підготовлених цифрових матеріалах подання одного й того самого повідомлення дуже гнучке i налаштовується згідно з індивідуальними потребами. Наприклад, поле виклику фонових повідомлень може відображатися в іншому місці, збільшуватися, підкреслюватися за допомогою кольору, повністю виділятися. Така гнучкість надає можливості для підвищення ясності сприйняття і значущості повідомлення для широкого кола учнів / студентів і коригування для інших.

Доступними у мобільних застосунках $є$ різні способи відображення даних у гнучкому форматі, що дозволяє змінювати такі функції сприйняття, як:

- розмір тексту, зображень, графіків, таблиць або іншого візуального вмісту;

- шрифт, який використовується для друкованих матеріалів;

- колір, що використовується для акценту;

- контраст між фоном і текстом або зображенням;

- компонування візуальних або інших елементів; 
- швидкість або час відео, анімації, звуку, симуляції тощо;

- гучність або швидкість мови або звуку.

2. Налаштувати альтернативні способи для сприйняття слухових повідомлень. Звук - це особливо ефективний спосіб передачі даних, саме тому звуковий дизайн настільки важливий у навчальних відео, і людський голос особливо ефективний для передачі емоцій і значень. Однак відомості, що передаються виключно за допомогою звуку, не однаково доступні для всіх учнів / студентів і $є$ особливо недоступними для осіб із вадами слуху, для тих, хто потребує більше часу на опрацювання даних, або для тих, хто має проблеми з пам'яттю. Крім того, саме слухання - це складна стратегічна навичка, яку треба засвоїти. Для того, щоб усі учасники освітнього процесу мали повноцінний доступ до навчання, повинні бути доступні варіанти для будь-якої інформації, включаючи акценти, подані на слух.

Освітні мобільні середовища дозволяють налаштувати декілька способів відображення альтернативи для слухових повідомлень:

- використання текстових еквівалентів у вигляді підписів або автоматизованого мовлення в текст (розпізнавання голосу) для розмовної мови;

- переклад мовою жестів;

- письмові стенограми для відео чи аудіокліпів;

- візуальні діаграми, нотації музики чи звуку;

- візуальні аналоги для представлення матеріалу (наприклад, смайлики, символи чи зображення);

- забезпечення візуальних чи тактильних (наприклад, вібрацій) еквівалентів звукових ефектів чи сигналів;

- наочний та / або емоційний опис для музичної інтерпретації.

3. Сучасні альтернативи для візуальних даних. Зображення, графіка, анімація, відео або текст часто $\epsilon$ оптимальним способом подання навчального матеріалу, особливо коли повідомлення стосується взаємодії між об'єктами, діями, числами або подіями, але такі візуальні уявлення не однаково доступні для всіх учнів / студентів, особливо для осіб із порушеннями зору або тих, хто не знайомий iз використовуваним типом графіки. Візуальне представлення може бути досить щільним, особливо у візуальному мистецтві, яке може мати кілька складних значень та інтерпретацій залежно від контекстуальних чинників і бази знань глядача. Щоб гарантувати, що всі учні / студенти мають однаковий доступ до навчального матеріалу, важливо забезпечити невізуальні альтернативи:

- текстовий або усний опис для усіх зображень, графіки, відео або анімації;

- слухові підказки для ключових понять і переходів до візуальних даних; 
- сенсорні еквіваленти (тактильні або об'єкти посилань) для ключових візуальних елементів, що представляють концепції.

Текст - це особливий випадок візуального повідомлення. Перетворення тексту в аудіо $є$ одним із найбільш легко здійснюваних методів підвищення доступності. Перевага тексту над аудіо полягає в його сталості, але наявність тексту, який легко трансформується у звук, дозволяє досягти цієї постійності, не жертвуючи перевагами аудіо. Цифрове синтетичне перетворення тексту в мову 3 використанням мобільних освітніх середовищ стає дедалі ефективнішим, хоча іноді розчаровує у своїй здатності нести якісний граматичний зміст.

Технологічний компонент використання мобільних освітніх середовищ передбачає можливість застосування в освітньому процесі сучасних методів і технологій навчання, необхідність оволодіння студентами відповідними знаннями й уміннями роботи 3 сучасними інформаційними ресурсами:

- умінням поєднувати традиційні та сучасні технології навчання у процесі навчально-пізнавальної діяльності;

- умінням самостійно працювати 3 різноманітними інформаційними джерелами, зокрема 3 електронними підручниками, посібниками, довідниками, конспектами (розуміти прочитане, систематизувати матеріал, конспектувати, робити тези, опорні схеми, таблиці тощо) та Інтернет-ресурсами (пошук, сприйняття, розуміння, відбір, аналіз, опрацювання, організація і представлення, збереження і передавання інформації);

- знанням технологій роботи із програмним забезпеченням загального призначення (сучасними пакетами математичних програм, текстовими та графічними редакторами, електронними таблицями для опрацювання числових даних, програмами створення презентацій, базами даних, електронними підручниками та посібниками);

- знанням алгоритмів, методів, прийомів і способів ефективного розв'язування задач за допомогою комп'ютера та мобільних застосунків (володінням навичками алгоритмізації, усвідомленням мобільних освітніх середовищ як універсального виконавця задач);

- умінням користуватися електронними засобами зв'язку (знанням способів передавання даних на відстані, використанням електронної пошти, впровадженням технологій віддаленого спілкування й навчання, функціонування комп’ютерних мереж тощо).

За умов змішаного та дистанційного навчання значимість мобільних освітніх середовищ значно зростає. Основна причина цього можливості, які вони надають: організація взаємодії студентів між собою, 3 викладачами, адміністрацією; спільна робота учасників освітнього процесу над завданнями аудиторно та в позааудиторний час; миттєвий обмін даними тощо. 
Науково-технічний прогрес істотно сприяє розширенню та вдосконаленню використання мобільних освітніх середовищ, оскільки сучасні портативні девайси стають легшими, дешевшими, з більшою роздільною здатністю екрана, більшим ресурсом акумулятора, підтримкою різного покоління передачі даних (3G, 4G, 5G Інтернету) та можливістю встановлення різноманітного програмного забезпечення. Тому мобільне навчання як галузь, що стрімко розвивається, розглядається деякими науковцями як навчання майбутнього, яке дозволяє незалежно від місця перебування, за комфортних умов опрацьовувати новий матеріал, працювати над закріпленням нових знань, самостійно перевіряти програмні результати навчання тощо.

Можливості й особливості використання сучасних цифрових технологій, зокрема вільного програмного забезпечення, різнобічно досліджуємо, аналізуємо та порівнюємо, а також активно використовуємо їх під час упровадження змішаної та дистанційної форм організації освітнього процесу.

Модель використання мобільних освітніх середовищ також забезпечує реалізацію принципів універсального дизайну у процесі навчання студентів інклюзивних груп педагогічних закладів вищої освіти ${ }^{7}$.

Пропонуємо розробникам мобільних освітніх середовищ дотримуватися певних рекомендацій:

- забезпечити доступ до програмного забезпечення перетворення тексту в мову (екранний диктор, наприклад, NVDA);

- дотримуватися стандартів доступності (NIMAS, DAISY та ін.) під час створення цифрового тексту;

- скористатися допомогою компетентного асистента або «посередника» у читанні тексту вголос.

Здатність учнів сприймати, інтерпретувати і розуміти інформацію залежить від засобів масової інформації та методів, за допомогою яких вона представляється. Для підтримки учнів 3 особливими освітніми потребами у навчальному середовищі необхідно забезпечити три види уявлень: варіанти сприйняття; варіанти мови, математичних виразів $\mathrm{i}$ символів; варіанти для розуміння ${ }^{8}$.

Учні / студенти можуть зазнавати труднощів через відсутність необхідних базових знань або розуміння контексту. Вони відрізняються за своєю здатністю отримувати й активувати ці знання, здатністю

7 Косовець О.П. Принципи універсального дизайну у методичній системі навчання інформатики учнів в інклюзивних групах. Научен вектор на Балканите. 2020. T. 4. № 2 (8). P. 14-17. DOI. 10.34671/SCH.SVB.2020.0402.0004.

${ }^{8}$ Косовець О.П. Особливості створення електронного підручника з інформатики для студентів 3 вадами здоров'я. Науковий часопис Національного педагогічного університету імені М.П. Драгоманова. Комп'ютерно-орієнтовані системи навчання. 2012. Вип. 12 (19). С. 185-189. 
знаходити та використовувати шаблони, необхідні для розуміння, здатністю узагальнювати та передавати знання. Вони сильно розрізняються у своїх знаннях словникового запасу, у швидкості розшифрування символів - від букв і слів до математичних символів, у їхньому розумінні структури мов та у знанні декількох мов. Особи з особливими освітніми потребами різняться за своїми вподобаннями та здібностями сприймати і працювати з різними навчальними матеріалами.

Учасники освітнього процесу розвивають різні навички швидкості (наприклад, візуальні, аудіо, математичні та ін.) завдяки використанню мобільних навчальних середовищ. Навчальні плани пропонують альтернативні способи, методи та форми організації освітнього процесу в доступних ступенях свободи, з високо захищеними і підтримуваними можливостями сучасних технологій. Вільне володіння також будується завдяки безлічі можливостей для виконання чи то у формі теоретичної підготовки, чи для виконання практики. Продуктивність допомагає учням / студентам, тому що вона дозволяє їм синтезувати своє навчання відповідно до особистих інтересів.

Загалом важливо розглянути варіанти, які розвивають швидкість навчання учнів засобами мобільних технологій через наявність:

- диференційованих моделей навчання (тобто моделей, що демонструють однакові результати, але використовують різні підходи, стратегії, навички та ін.);

- індивідуальних моделей навчання (моделей, які синтезовані відповідно до особистих інтересів учнів);

- групових моделей навчання (моделей, синтезованих відповідно до інтересів певних груп учнів);

- наставників у класі (тобто асистентів, котрі використовують різні підходи для мотивації, зворотного зв'язку або допомоги);

- диференційованого зворотного зв'язку за допомогою сучасних технічних засобів.

Нині застосовуються і добре себе зарекомендували такі мобільні програмні засоби та сервіси:

- Google-сервіси (GoogleClassroom, GoogleDrive, Gmail, GoogleMeet, GoogleSites, YouTube та ін.) - для комунікації та спільної роботи 3 документами;

- Skype, Viber, Zoom, Telegram, WhatsApp - засоби інтернеттелефонії;

- GeoGebra, Photomath, MalMath, FreeGraCalc, Desmos, QuckGraph+, GeometryPad, TriangleSolve, iCrosss, ToolKitPro, SmartMeasure тощо мобільні додатки математичного спрямування;

- Matific, GIOS, Learning.ua, Quick Brain, Fractionsforkids, ua.OnlineMSchool.com, GeometryPad, ICrosss, Euclidea, Піфагорія, Король математики тощо - математичні ресурси для змішаного навчання шкільного курсу математики. 
Таким чином, реалізація технологічного блоку передбачає забезпечення продуктивного зворотного зв'язку між науковопедагогічними працівниками та здобувачами вищої освіти у процесі навчання; ефективну комунікацію між викладачем i студентами; конструктивну реакцію викладача на освітні запити та потреби студентів.

Результативний блок моделі використання мобільних освітніх середовищ містить форми та методи онлайн-оцінювання, що забезпечують валідність оцінювання успішності студентів і встановлення факту досягнення результатів навчання; критерії оцінювання, які описують те, що здобувач освіти здатний виконувати для демонстрації здобутого результату навчання. Форми (методи) та критерії оцінювання узгоджуються з результатами навчання і з видами навчальної діяльності, які реалізовувалися у процесі навчання. Форми проведення контрольних заходів у межах навчальних дисциплін обираються викладачами залежно від особливостей вивчення освітніх компонентів і прогнозованих програмних результатів навчання.

Отже, створення й використання мобільних освітніх середовищ у процесі навчання студентів педагогічних закладів вищої освіти вимагає правильного відбору змісту навчання відповідно до дидактичних властивостей і можливостей засобів цифрових технологій навчання; прогнозу можливого їх впливу на характер мислення і поведінки учасників освітнього процесу тощо.

\section{2. Використання мобільних технологій і засобів навчання у закладах освіти: переваги, недоліки та вимоги до застосування}

В українських закладах загальної середньої освіти стандартними засобами навчання математики $\epsilon$ набір геометричних фігур, креслярських інструментів (циркуль, транспортир, лінійка, трикутник тощо), поліграфічні матеріали (стенди, таблиці, плакати тощо). Сукупність цих об'єктів повністю або частково замінює поняття, що вивчається, надає загальну інформацію про нього, дозволяє візуалізувати основні характеристики, досліджувати властивості, перевіряти достовірність правил, аксіом i теорем, здійснювати моніторинг досягнення учнями результатів навчання (компетентностей). Нині всі ці засоби навчання можна доповнити та / або замінити сучасними інформаційними технологіями та мобільними додатками.

Нині смартфони та планшети активно залучаються до освітнього процесу у традиційній школі. Школярі можуть не носити портфелі 3 великою кількістю підручників. Тепер вся необхідна інформація може міститися в одному пристрої. Мобільні технології та засоби навчання, що поєднують широкий спектр цифрових і повністю портативних мобільних пристроїв (смартфонів, планшетних комп'ютерів, електронних книг тощо), дозволяють здійснювати дії щодо створення, збирання, зберігання, обробки, відображення, передавання, розповсюдження, використання, захисту інформації. 
Цифрові технології швидкими темпами проникають у сферу освіти. Цей процес ефективно розвивався від навчання математики за допомогою навісної дошки та різнокольорової крейди до навчання на інтерактивній дошці; від використання рахівниці, пізніше калькулятора - до девайсів, за допомогою яких нині з'явилася можливість розв'язувати різноманітні математичні задачі. Розмірковуючи про переваги наявності ноутбуків у класі, зауважимо, що найчастіше вони використовуються вчителями для демонстрації різних навчальних презентацій і відео, але зараз настала епоха мобільних технологій і їх широкого використання в усіх освітніх галузях, завдяки чому з'явилася навіть нова технологія навчання, а саме мобільне навчання (e-learning), тобто навчання за умов, коли учень / студент має мобільний доступ до освітніх ресурсів, може на відстані взаємодіяти 3 учителем / викладачем та іншими учасниками освітнього процесу.

Переваги використання мобільних технологій і засобів навчання $\epsilon$ загальновідомими, тому зростає кількість педагогів, які дозволяють використовувати планшети та смартфони з відповідним програмним забезпеченням на уроках, зокрема математики, як додаткову допомогу в навчанні. Водночас консервативніші учителі занепокоєні тим, що мобільні пристрої можуть відволікати учнів від навчального процесу. Інші переконані, що мобільні технології та засоби - це не лише модна іграшка, а й сучасний інструмент для навчання. Тільки в AppleAppStore $\epsilon$ понад 15000 освітніх додатків, а ще $\epsilon$ GooglePlay, windowsphonestore тощо. Їхні програми мають багато навчальних матеріалів для будьякого віку та предметної сфери.

Очевидно, що подеколи хвилювання учителів $є$ цілком зрозумілим і виправданим, проте переоцінити переваги мобільних технологій і засобів навчання у закладах загальної середньої освіти складно 3 низки причин:

1. Простота у використанні. Сучасні учні з дитинства знають, що таке планшет чи смартфон, тому їм інтуїтивно легше знайти потрібну інформацію за допомогою цих засобів, ніж у комп'ютерах чи підручниках.

2. Доступний і зручний взаємозв'язок між учнями, учителями та батьками. Навмисно чи випадково учень може не записати домашне завдання чи будь-яку іншу актуальну інформацію, загубити паперовий підручник, зошит або щоденник, не розповісти чи не попередити батьків про певну важливу подію зі свого шкільного життя тощо. Цього не можна сказати про цифрові дані. Всі зауваження чи похвали, практичні робити чи домашні завдання, хороші та погані оцінки завжди будуть доступні для перегляду учням і батькам, іншим зацікавленим особам. І такі поняття, як «не знав» чи «забув» більше не приймаються. Тобто розширюються можливості взаємодії учнів, учителів, батьків та 
інших учасників освітнього процесу, що особливо актуально під час організації змішаного / дистанційного навчання.

3. Доступна база знань. За допомогою пристроїв із відповідним програмним забезпеченням, електронними бібліотеками чи доступом до мережі Інтернет стає можливим пошук актуального навчального матеріалу в режимі реального часу, використання рекомендованих учителем додаткових інформаційних ресурсів під час підготовки до занять, екзаменів чи зовнішнього незалежного оцінювання тощо. Мобільні пристрої легко можуть замінити друковані підручники, посібники чи зошити. Якщо підручник містить навчальний матеріал, розміщений у відкритому доступі в мережі Інтернет, учасники освітнього процесу зможуть самостійно знайти необхідну інформацію, перейшовши на відповідне посилання чи за допомогою QR-коду. Крім того, є можливість зберігати веб-сторінки та переносити їх із одного пристрою на інший i, не використовуючи Інтернет, відкривати збережені копії сторінок.

4. Персональний підхід. Вчитель-новатор має володіти різними стилями викладання, використовувати сучасні методи й методики навчання 3 урахуванням індивідуальних, освітніх, вікових, психологічних особливостей учнів. Щоб подолати певні бар'єри взаємодії з учнівським колективом, він може використовувати мобільні технології й засоби навчання, електронні ресурси тощо. Подібні освітні інструменти в сукупності / системі з індивідуальними навчальними планами та можливістю використовувати їх у зручний час і в комфортному місці оцінять учні з обмеженими можливостями.

5. Мобільні технології рентабельні, тобто у довгостроковій перспективі планшети та смартфони є розумною інвестицією. Зокрема, $\epsilon$ можливість завантажити PDF-версії книг, підручників, робочих зошитів, установити необхідне програмне забезпечення та інші важливі додатки, налагодити швидкий онлайн-доступ до вільно поширюваних освітніх ресурсів тощо, встановити спеціальне програмне забезпечення або застосувати додаткові налаштування смартфону, ноутбука учня з особливими освітніми потребами, тобто зосередити всі необхідні навчальні інструменти в одному пристрої.

6. Легка, швидка та якісна візуалізація. Реалізовуючи принцип наочності, мобільні технології та засоби навчання $є$ відмінним стимулом для створення візуальної підтримки будь-якого заняття, адже чим різноманітнішим $\epsilon$ унаочнення матеріалу уроку, тим доступнішим буде пояснення навчального матеріалу. 3 іншого боку, учні / студенти можуть фотографувати приклади, розв'язані на дошці чи записувати на відео чи аудіо пояснення вчителя / викладача, якщо не встигають зробити конспект.

7. Удосконалення навичок роботи із сучасними технологіями. Варто визнати, що комп'ютери 3 відповідним програмним забезпеченням $\epsilon$ незамінними помічниками та багатофункціональними виконавцями 
операцій у різноманітних сферах життєдіяльності людини, тому важливо навчитися ними користуватися ще зі школи. Цьому сприяе успішне вивчення шкільного курсу інформатики. Крім того, зручний формат планшету покращує креативність у підготовці до занять, а мобільні додатки допомагають в організації групової та індивідуальної діяльності учнів на відстані тощо. Саме за допомогою мобільних технологій i засобів навчання сучасні учні / студенти стали не пасивними одержувачами знань, а повноцінними учасниками освітнього процесу під час організації змішаної та дистанційної форм навчання.

8. Швидке та неупереджене оцінювання. Використовуючи онлайнтестування, не потрібно тратити багато часу на перевірку робіт. Тепер усі оцінки та рівень досягнення програмних результатів навчання учнів можна перевірити за допомогою дотику до екрана вашого смартфону. Аналіз отриманих результатів допоможе визначити подальшу траєкторію освітнього процесу: на чому варто акцентувати увагу під час пояснення нового матеріалу чи повторення теми, який підхід до учнів потрібно обрати тощо.

9. Екологічний ефект. Під час використання й утилізації канцелярії варто пам'ятати про проблеми екологічного характеру через вирубку лісів, не забувати про забруднення навколишнього середовища через виробництво шкідливого пластику тощо. Мобільні технології допоможуть заохотити людство відмовитися від речей, які не настільки потрібні та які потенційно можуть опинитися у смітнику.

10. Ігри для розвитку. Гра може бути не лише дарма втраченим часом i способом відволікти увагу від навчання, а ще і надихнути дитину на творчість i прийняття нестандартних рішень. Навіть звичайний додаток на смартфоні для вивчення усного рахунку уже $\epsilon$ правильним вибором для проведення вільного часу.

11. Гаджети знімають психологічне навантаження, яке відчуває дитина. На смартфоні, що знаходиться завжди під рукою, є улюблені фото, відео або музика, які піднімають настрій. Єдина умова використання навушників, щоб не заважати іншим.

12. Безпека. За допомогою мобільного телефону та меседжерів можна швидко повідомити батькам про надзвичайну ситуацію, що трапилася 3 дитиною у школі, за потреби повідомити учасникам освітнього процесу актуальну інформацію тощо. Щоб забезпечити безпеку в Інтернеті, батьки користуються функцією батьківського контролю, що дозволяє їм обмежити час використання електронних пристроїв дітьми, блокувати доступ до онлайн-ресурсів із небажаним контентом.

Поряд із перевагами необхідно також описати недоліки мобільного навчання, що виникають через недоцільне використання мобільних технологій і засобів навчання:

1. Відволікаючий чинник. Стосується всіх учасників освітнього процесу. Важко сфокусувати увагу на навчальній діяльності, коли $€$ можливість використати Інтернет задля розваг. 
2. Технічні обмеження. По-перше, виникають через нерівномірне Інтернет-покриття різних регіонів i населених пунктів, непристосованість освітніх закладів до масового використання мобільних пристроїв на уроках. Зокрема, класні кімнати мають бути обладнані достатньою кількістю розеток, оскільки ці пристрої швидко розряджаються. По-друге, багато планшетів i смартфонів не підтримують багатозадачність, що викликає незручності за необхідності тримати відкритими декілька вікон одночасно. Компактні розміри пристроїв викликають дискомфорт, особливо під час читання електронних книг.

3. Матеріальні можливості. Не у всіх є можливість купувати одразу якісні мобільні пристрої, які прослужать достатньо довго. Також діти менш дбайливо ставляться до їх використання, тому можуть загубити чи розбити свій планшет, що спричинятиме додаткові витрати для батьків.

4. Акомодація методики навчання. Не всі науково-педагогічні працівники хочуть додатково витрачати свій час на підвищення власної інформаційної та інформатичної компетентності чи адаптувати свою методику навчання до впровадження мобільних технологій і засобів навчання. Також не додає ентузіазму недостатня кількість якісних додатків та іншого переробленого й адаптованого контенту для мобільних пристроїв.

5. Здоров'я. Особливому ризику порушення зору піддаються здобувачі освіти, котрі практично не відривають очі від моніторів. Масове використання мобільних пристроїв у школі тільки погіршить ситуацію. Розмір смартфона чи планшета, особливо за низької роздільної здатності екрану, вкрай незручний для роботи з текстом. Варто не забувати про психологічне здоров'я учнів і прояви Інтернетзалежності, тому процес використання мобільних технологій і засобів навчання повинен підлягати особливому контролю з боку вчителів і батьків.

6. Безпека. За даними Дитячого фонду ООН (ЮНІСЕФ), у 2019 р. $32 \%$ українських дітей віком від 11 до 17 років були жертвами кібербулінгу. Кіберагресори створюють публікації, що принижують гідність жертв, надсилають їм повідомлення з погрозами, викладають фотографії та відео зі знущаннями 9 . Також девайси атакують віруси, здатні пошкодити або видалити інформацію, та шахраї, тому залякана дитина може втратити значні кошти.

Враховуючи вищеназвані переваги й недоліки використання мобільних технологій і засобів навчання, вважаємо, що мобільні застосунки мають відповідати таким вимогам, як:

1. Ергономічність. Через малий розмір екрану дизайн мобільних застосунків має бути якісним, тобто розміщення кнопок, надписів тощо

9 Рекомендации ЮНЕСКО по политике в области мобильного обучения. 2015. 44 c. URL: http://iite.unesco.org/pics/publications/ru/files/3214738.pdf 
має бути зручним, а кольорові акценти - вказувати на те, що важливо запам'ятати. Застосунок повинен мати високу якість відтворення зображення, звуку, відео. Для швидкого завантаження всіх елементів програми потрібен малий розмір вихідного файлу.

2. Доступність. Українські провайдери мають найдешевший у Свропі та четвертий за доступністю у світі мобільний Інтернет i зв'язок ${ }^{10}$. Доступ до Інтернету - це важливо, оскільки багато мобільних застосунків не працюють за його відсутності. Завдяки Інтернету учасники освітнього процесу можуть у будь-якому місці отримати доступ до навчального застосунку чи вільно поширюваного інформаційного контенту.

3. Компактність. 3 огляду на те, що за допомогою мобільних застосунків можна навчатися самостійно, виклад навчального матеріалу має бути коротким за тривалістю та доступним для самостійного опрацювання.

Часто діти працюють разом, щоб знайти вирішення навчальної проблеми, і це необхідно заохочувати, а не називати «шахрайством», тому що політика заборони мобільних пристроїв недалекоглядна й застаріла. Використання мобільних технологій і засобів навчання має свої недоліки, але їхня еволюція надає можливість розвивати та вміщувати в мобільних застосунках ті інструменти, що не доступні у традиційній школі.

Сучасні цифрові технології дозволяють повноцінно включати в освітній процес учнів / студентів із особливими освітніми потребами засоби унаочнення, візуалізації, відео та звукозапису навчального матеріалу з урахуванням їхніх індивідуальних здібностей.

За умов реалізації лише традиційних форм навчання ситуація була не настільки однозначною, оскільки більшість учасників освітнього процесу не використовували цифрові технології саме в навчальних цілях. Значна частина науково-педагогічних і педагогічних працівників не виявляли особливого бажання змінювати або доповнювати загальновідомі й перевірені часом методики навчання. Як результат, нерідко навчання було на кілька кроків позаду інновацій, однак карантин i запровадження змішаного й дистанційного навчання в закладах освіти внесли радикальні зміни в організацію освітнього процесу з використанням мобільних технологій і засобів навчання.

\section{ВИСНОВКИ}

Впровадження мобільних технологій і засобів навчання в освітній процес в Україні наштовхується на низку проблем i перешкод, пов'язаних із переважанням традиційних підходів в освіті, iiï недостатньою динамічністю; зі специфікою їх використання в

${ }^{10}$ Скрипник Г.В. Використання мобільних додатків для проведення навчальних досліджень під час вивчення предметів природничо-математичного циклу. Комп 'ютер у школі та сім'ї. 2015. № 3. С. 28-31. 
регіонах, зокрема, нерівномірним доступом до мережі Інтернет і різним матеріальним становищем українських родин, із вмотивованістю, готовністю та здатністю вчителів та учнів, викладачів і студентів використовувати мобільні технології та засоби навчання для надання й отримання освітніх послуг, але використання технологій мобільного навчання дає широкі можливості поповнити багаж знань, підвищити професійну кваліфікацію, розвинути креативність, сформувати інформаційно-комунікаційну й інформатичну компетентності учасників освітнього процесу.

Швидкість розвитку сучасних цифрових технологій надзвичайно висока. Поруч із ними змінюється та зростає суспільство, що свідчить про те, що кожен громадянин вже зараз потребує самоосвіти для змоги «йти в ногу» із часом і гармонійно почуватися в навколишньому середовищі. I хоча мобільне навчання не спроможне повністю замінити повноформатну освіту, воно здатне забезпечити освітній ріст особистості, вирішити питання безпеки життєдіяльності за умов пандемії. Крім того, використання мобільних технологій і засобів навчання вимагає ретельного відбору та відпрацьовування методик навчання, аналізу пріоритетних чинників, які впливають на ефективність роботи, та співпраці учасників освітнього процесу в дистанційному навчальному середовищі, врахування матеріальнотехнічних можливостей закладів освіти, здобувачів і педагогічних працівників тощо.

Слід чітко усвідомлювати, що в сучасному світі мобільне навчання, особливо дистанційне, - це швидше вимушена необхідність, аніж вільний вибір громадянського суспільства. Тому варто цінувати ті перспективи, які воно надає: доступ до нетрадиційних джерел інформації, урізноманітнення самостійної роботи, цілковито нові можливості для творчості, самореалізації й саморозвитку, розвиток і вдосконалення різних професійних навичок, необхідність реалізовувати принципово нові форми й методи навчання із використанням цифрових технологій тощо. Доречно пам'ятати про взаємозалежність ефективності такого навчання та грамотної організації освітнього процесу за наявності відповідних матеріально-технічних можливостей в учасників освітнього процесу.

\section{АНОТАЦІЯ}

У статті наведена загальна характеристика мобільних технологій і засобів навчання у закладах загальної середньої та вищої педагогічної освіти. Представлено модель використання мобільних освітніх середовищ у процесі навчання студентів педагогічних закладів вищої освіти як системне поєднання цільового, змістового, технологічного та результативного структурних блоків. Зроблено аналіз цифровізації освіти задля забезпечення доступу й підвищення якості освітнього процесу учнів / студентів із особливими освітніми потребами через мобільні освітні середовища. 
Висвітлено переваги використання мобільних технологій і засобів навчання, а саме: простоту у використанні; доступний i зручний взаємозв'язок між учнями, учителями та батьками; доступну базу знань; персональний підхід; легку, швидку та якісну візуалізацію навчального матеріалу; удосконалення навичок роботи із сучасними технологіями; швидке й неупереджене оцінювання; екологічний ефект; ігри для розвитку; психологічне розвантаження; безпеку. У статті також перелічено недоліки: відволікаючий чинник; технічні обмеження; матеріальні можливості; акомодацію методики навчання; вплив на здоров'я; онлайн-небезпеки. Автори статті наголошують на тому, що мобільні застосунки мають відповідати таким вимогам, як ергономічність, доступність і компактність.

3'ясовано, що особливого значення набувають мобільні технології за педагогічно виваженого використання, доцільної інтеграції мобільних освітніх середовищ у традиційне інформаційно-освітне середовище закладів загальної середньої та вищої педагогічної освіти.

\section{ЛITEPATУРA}

1. Лазаренко Н.І., Коломієць А.М., Клименко А.О. Симбіоз методологічних підходів до розвитку освіти в умовах інформаційного суспільства. Наука і освіта. 2017. T. 4. C. 107-112. DOI: 10.24195/24144665-2017-4-18.

2. Semenets D.A., Soia O.M., Tyutyun L.A. Using of electronic educational content in higher education institutions. Фізико-математична освіта. 2020. Вип. 1 (23). Ч. 2. С. 6-11. DOI: 10.31110/2413-1571-2020023-1-2-001

3. Тютюн Л.А., Соя О.М. Забезпечення E-learning за допомогою персонального сайту викладача. Сучасні інформаційні технології та інноваційні методики навчання: досвід, тендениї̈, перспективи : збірник наукових праць II Міжнар. наук.-практ. інтернет-конф. з нагоди святкування 30-річчя кафедри інформатики та методики ііі навчання (м. Тернопіль, 8-9 листоп. 2018 р.). Тернопіль, 2018. С. 247-249. URL: http://conf.fizmat.tnpu.edu.ua/media/arhive/2018.pdf.

4. Серга O.М., Соя О.М. Використання мобільних технологій навчання математики в закладах загальної середньої освіти. Проблеми вищої математичної освіти: виклики сучасності : матеріали Міжнар. наук.-метод. Інтернет-конф. (м. Вінниця, 01-03 червня 2020 р.). Вінниця, 2020. URL: https://conferences.vntu.edu.ua/index.php/pmovc/ pmovc20/paper/view/10493.

5. Соя О. Використання навчального контенту онлайн-середовищ у професійній підготовці майбутніх учителів інформатики та математики. Наукова діяльність як шлях формування професійних компетентностей майбутнього фахівия : матеріали Міжнар. наук.-практ. конф. (м. Суми, 5-6 грудня 2019 р.). Суми, 2019. Ч. 2. С. 156-158.

6. Semenets D.A., Soia O.M., Tyutyun L.A. Functioning of virtual educational environments in higher education in context of continuous education. Progressive Science Journal. 2019. № 1. P. 28-32. 
7. Косовець О.П. Принципи універсального дизайну у методичній системі навчання інформатики учнів в інклюзивних групах. Научен вектор на Балканите. 2020. Т. 4 . № 2 (8). Р. 14-17. DOI: 10.34671/SCH.SVB.2020.0402.0004.

8. Косовець О.П. Особливості створення електронного підручника 3 інформатики для студентів 3 вадами здоров'я. Науковий часопис Національного педагогічного університету імені М.П. Драгоманова. Комп'ютерно-орієнтовані системи навчання. 2012. Вип. 12 (19). C. $185-189$.

9. Рекомендации ЮНЕСКО по политике в области мобильного обучения. 2015. 44 c. URL: http://iite.unesco.org/pics/publications/ru/ files/3214738.pdf.

10. Скрипник Г.В. Використання мобільних додатків для проведення навчальних досліджень під час вивчення предметів природничо-математичного циклу. Комп'ютер у школі та сім'ї. 2015. № 3. C. 28-31.

\section{Information about the authors:} Soia O. M., Candidate of Pedagogical Sciences,

Senior Lecturer at the Mathematics and Computer Science Department of the Faculty of Mathematics, Physics, Computer Science and Technology

Vinnytsia Mykhailo Kotsiubynskyi State Pedagogical University 32, Ostrozki str., Vinnytsia, 21000, Ukraine

Tyutyun L. A.,

Candidate of Pedagogical Sciences, Associate Professor, Associate Professor at the Mathematics and Computer Science Department of the Faculty of Mathematics, Physics, Computer Science and Technology

Vinnytsia Mykhailo Kotsiubynskyi State Pedagogical University 32, Ostrozki str., Vinnytsia, 21000, Ukraine

Kosovets O. P., Candidate of Pedagogical Sciences,

Senior Lecturer at the Mathematics and Computer Science Department of the Faculty of Mathematics, Physics, Computer Science and Technology Vinnytsia Mykhailo Kotsiubynskyi State Pedagogical University 32, Ostrozki str., Vinnytsia, 21000, Ukraine 